\title{
THE INDIVIDUAL AND COLLECTIVE MEANING OF THE NOTION OF EMPLOYER IN POLISH LEGAL SYSTEM
}

\begin{abstract}
This article aims to identify the normative relationships between the notion of employer defined in individual labour law and collective labour law. The paper covers problems relating to both theoretical and practical problems.
\end{abstract}

Słowa kluczowe: pracodawca, prawo pracy, prawo zatrudnienia, zbiorowe prawo pracy

Keywords: employer, labour law, employment law, collective labour law

ASJC: 3308, JEL: K31

In the Polish employment law system, one may distinguish between two fundamental notions of the employer, which are: the employer as defined in individual labour law (Art. 3 of the Labour Code) and the employer as defined in the collective labour law (Art. $1^{1}$ item 2 of the Act on Trade Unions). The aim of this study is to identify the normative relationships between these two notions.

The starting point for further dogmatic analyses will be the statement that the objective scopes of both these terms partly correlate. However, this generates a series of both theoretical and practical problems.

Let me start the discussion on the notion of the employer from its "individual" meaning defined in Art. 3 of the Labour Code. It is fundamental, as it has been also implemented in Art. $1^{1}$ item 2 of the Act on Trade Unions. In the light of Art. 3 of the Labour Code, the general prerequisite for acquiring the status of an employer is employing employees (cf. judgment of the Supreme Court of 13 March 2012, II PK 170/11, LEX 1211150, thesis 2). This term should be interpreted in the context of the factors foreseen in Art. $22 \$ 1$ of the Labour Code. This means that work is performed personally and voluntarily, in return for remuneration, in the conditions of functional subordination. There may be only one employer under a specific work relationship (cf. judgment 
of the Supreme Court of 15 March 2018, I PK 369/16, LEX 2508615). However, this does not apply to temporary work.

Pursuant to the provisions of Art. 3 of the Labour Code, the employer may be (Hajn 2017, p. 144 and the literature) an organisational unit (Kaczyński 1998, p. 38) or an individual, which employs employees. Here, it may seem doubtful whether employing only one employee may result in acquiring the status of an employer, considering that the provision in question uses the plural form. However, if one uses the purposive interpretation, it seems justified to apply interpretatio extensiva and to assume that the meaning of the provision is wider than its linguistic scope, according to the formula minus dixit quam voluit. As a result, the status of an employer will be attributed also to entities that employ only one employee. At the same time, it is insignificant, whether the employee is employed on a full-time or part-time basis and on what kind of act creating the employment relationship the employment is based.

When analysing the terminological aspect, it should be emphasised that de lege lata a work establishment does not have the status of an employer. Currently, this term has mainly an objective meaning (on the meaning of the notion "work establishment", see Korus 2017, pp. 7-8), which refers to the set of distinctive property elements (e.g. offices, manufacturing plants or shops; see judgment of the Supreme Court of 19 April 2010, II PK 298/09, LEX 602256), where the work process takes place (e.g. Art. 207 of the Labour Code). Hence, using the term in a subjective dimension is normatively unjustified. In this respect, it is worth noting the relevant view of the Supreme Court (cf. judgment of the Supreme Court of 23 February 1999, IPKN 594/98, OSNP 2000, No. 8, item 299), stating that an organisational unit specified as the place of work is not an employer. The employer is a natural person conducting business activity, not the enterprise managed by such person understood as a set of organised tangible and intangible elements designated for conducting business activity (cf. judgment of the Supreme Court of 29 October 2014, I PK 64/14, MPP 2015, No. 4, pp. 206-209).

In the light of the provisions of Art. 3 of the Labour Code, the employer (on the ability to be an employer, see judgment of the Supreme Court of 25 September 2008, II PK 36/08, MPP 2009, No. 10, p. 532) is an organisational unit, even if it does not have legal personality. In this aspect, legal personality does not constitute a distinguishing criterion, which means, in practice, that both organisational units that have such legal personality and those without it are equal as parties to the employment relationship.

The analysis of organisational unit will start with those that have legal personality. In the Polish legal system, an organisational unit obtains legal personality at the moment of entry in the relevant registry, e.g. the National Court Register (KRS) (Art. 33 of the Civil Code). The nature of such entry is constructive, which usually entails legal, organisational, and property distinction. In some cases, norms of the statutory or executive rank grant legal personality individually to specific units or structures, e.g. the Polish Academy of Sciences. 
The organisational units that have a legal personality and the status of an employer are state-owned enterprises, commercial companies, ${ }^{1}$ co-operatives, agencies, primary and secondary schools (cf. judgment of the Supreme Court of 11 September 1998, II UKN 196/98, OSNP 1999, No. 18, item 589), universities, research institutions and associations, ${ }^{2}$ foundations, healthcare facilities, political parties, civil organisations, associations of employers, and even trade unions. The list above is not of an enumerative nature. It is only an illustration presenting some of the entities that have such status in the light of the provisions of Art. 3 of the Labour Code. From the point of view, the ownership status of such organisational units is insignificant, so that in industrial relations the ownership-based concept of employer is superseded by the management-based concept (cf. judgment of the Supreme Court of 14 February 2018, I PK 351/16, LEX 2486199; judgment of the Administrative Court in Katowice of 25 October 2018, III APa 82/17, LEX 2612144), pursuant to which the employer is the one who manages the property and the structure operating within it. In the light of the provisions of Art. 3 of the Labour Code, it is the temporary employment agency (cf. judgment of the Supreme Court of 4 June 2014, IIUK 565/13, LEX 1475235) that has the status of an employer, not the employer who uses the services of such agency (cf. judgment of the Supreme Court of 10 April 2014, I PK 243/13, LEX 1486963). However, this does not mean that the latter is not responsible for damages caused to the temporary employee, for example under Art. 435 of the Civil Code. In practice, in many situations we are dealing with a dual responsibility distributed between the temporary employment agency and the user employer.

In structurally complex entities identifying the employer may pose certain difficulties. The main problem is the status of internal organisational units. In practice, it applies mainly to companies (Wąż 2007, p. 124). The starting point for further considerations will be the thesis that, based on doctrinal (Hajn 1997, p. 21) and judicial (cf. judgment of the Administrative Court in Katowice of 14 December 2012, III APa 25/12, LEX 1259682) findings, such organisational unit may have the status of an employer, if it was assigned the ability to employ employees on its own behalf and if it has been organisationally and financially distinguished. De lege lata, holdings (cf. judgment of the Supreme Court of 5 September 2017, II UK 365/16, LEX 2401069) or capital groups are not employers.

The ability to employ employees on its own behalf must be based on the acts regulating the organisation of a legal entity (e.g. the Statutes of a Company) or in the acts of its governing bodies creating its organisational structure (e.g. the resolutions of the Management Board of a company). They should define the entities (bodies or persons)

\footnotetext{
1 A joint stock company may be the employer of the director of its branch office; cf. judgment of the Supreme Court of 20 September 2005, II PK 413/04, OSNP 2006, No. 12-14, item 211.

2 In the judgment of 14 June 2006 I PK 231/05 (OSNP 2007, No. 13-14, item 183), the Supreme Court expressed the opinion that non-public schools that are managed by educational accosiations and do not have a organisational and property independence and do not employ employees on their own behalf, are not the employers of the teachers who are employed there.
} 
authorised to make statements of will on its behalf as the employer (Piwowarczyk 2005, p. 130 and literature referenced therein). This means that an internal structure, whose manager enters into and terminates employment relationships pursuant to an authorisation (appointment) granted under Art. $3^{1}$ of the Labour Code by a superior organisational unit whose part the given unit is, will not have the status of an employer.

Another precondition for assigning the status of an employer to an internal organisational unit is its organisational and financial separation. It is characterised by distinguishing the unit formally from the structures of an organisational unit possessing legal personality and by a distinctive financial status (e.g. separate bank accounts). In the second aspect, this means the right to dispose of the entrusted financial means independently (cf. judgment of the Voivodeship Administrative Court in Warsaw of 12 December 2006, III SA/Wa 1681/06, LEX 328557) as part of individual economic accounting. As it seems, in financial terms, the minimum standard is to have a separate remuneration fund, from which the employees are paid their remunerations. Here, it should be emphasised that the entity that actually (cf. judgment of the Supreme Court of 1 February 2000, I PKN 494/99, OSNP 2001, No. 12, item 409) pays remuneration to employees is not always the employer. Organisational structures separated based on the functional criterion only, to perform specific manufacturing or service tasks (e.g. departments of an industrial concern) do not have the status of an employer.

An internal organisational unit (e.g. a branch office, plant, or division; cf. judgment of the Voivodeship Administrative Court in Warsaw of 26 June 2008, III SA/Wa 266/08, LEX 402907) that employs employees independently usually does not have legal personality. Thus, it belongs to the category of employers who are not legal entities. However, under Art. 3 of the Labour Code, they are granted legal capacity with respect to labour law. This group of employers may also include so-called incomplete legal entities as defined in Art. $33^{1}$ of the Civil Code. This refers mainly to commercial partnerships, in particular partnerships (Zając 2010, pp. $22 \mathrm{ff}$ ), limited partnerships, private unlimited partnerships with share capital, and registered partnerships. As far as the last category is concerned, this view was reflected in the judgments of the Supreme Court (cf. judgment of 4 November 2004, I PK 25/04, OSNP 2005, No. 14, item 206), which stated that it was the registered partnership that was the employer, not the partners.

The labour law doctrine (Ćwiertniak 2010, pp. 162-163; Hajn 2017, pp. $151 \mathrm{ff}$ ) and jurisprudence (cf. resolution of the Supreme Court of 16 November 1977, I PZP 47/77, OSP 1979, No. 7, item 125; judgment of the Supreme Court of 19 April 1979, IPR 16/79, OSNC 1979, No. 10, item 205) formulate additional requirements for employers who do not have a legal personality. The above refers to a regulated structure that allows the unit to manage its own affairs in internal relations and property separated from the property of members or founders. In the latter aspect, the organisational unit does not have to have a title of ownership. It is sufficient if it is able to dispose of property elements that are necessary to employ employees.

Various problems concerning the definition of the status of an employer have emerged not only in industrial relationships, but also in widely understood public administration. 
It is doubtless that the State Treasury does not have the status of an employer (cf. decision of the Supreme Court of 15 December 2009, II PZ 23/09, LEX 577835; Hajn 2017, pp. 150-151), as it is not an organisational unit, but a normative entity. In the public sphere, employers are mainly statio fisci of the Treasury.

In this context, the question arises, who, specifically: is it the entity managing the unit, or maybe the superior unit, or is it the unit itself that employs an employee and has the status of an employer? The jurisprudence of the Supreme Court, guided by the textual interpretation of Art. 3 of the Labour Code, considers public administration offices (cf. judgment of the Supreme Court of 19 December 1997, IPKN 448/97, OSNP 1998, No. 22, item 649), courts (cf. resolution of the Supreme Court of 23 July 1993, I PZP 30/93, OSNCP 1994, No. 6, item 123; judgment of the Supreme Court of 2 December 2010, I CSK 111/10, LEX 1001270), prosecutor's offices (resolution of the Supreme Court of the 29 July 2003, III PZP 8/03, OSNP 2004, No. 5, item 75), regional labour inspectorates (resolution of the Supreme Court of 24 November 1992, I PZP 59/92, OSNCP 1993, No. 4, item 49), the Superintendent of Schools Office (cf. decision of the Supreme Court of 22 June 2015, I PZ 8/15, OSNP 2017, No. 3, item 31), and local offices of the Supreme Chamber of Control to be employers. In my opinion, similar mechanisms should be applied to local territorial self-government (cf. judgment of the Supreme Court of 3 June 2014, III PK 128/13, LEX 1486980) so it should be assumed that Marshall's Offices, Staroste's offices, municipal offices and other self-government structures (cf. judgments of the Supreme Court: of 20 October 1998, I PKN 390/98, OSNP 1999, No. 3, item 744; of 4 January 2008, I PK 187/07, LEX 375669; of 4 March 2010, I PK 177/09, LEX 585690; of 18 September 2013, II PK 4/13, LEX 1375183; cf. e.g. budgetary establishments; see judgment of the Supreme Court of 14 December 2004, I PK 135/04, OSNP 2005, No. 15, item 224) have the status of an employer.

Declaring the bankruptcy of an employer does not directly affect its status as a party to the employment relationship (Tomanek 2004, pp. $22 \mathrm{ff}$ ). However, neither the administrator, nor the receiver or court supervisor has the status of an employer. These are the persons appointed to substitute for the employer in performing actions in cases related to labour law pursuant to Art. $3^{1} \$ 1$ of the Labour Code. The above remarks apply to various forms of insolvency.

The status of an employer as a subject of the employment relationship does not change when its name or legal form of activity change. Only the transfer of a work establishment or a part thereof results in a change of the employer. This takes place in the manner defined in Art. $23^{1}$ of the Labour Code or in specific regulations.

In the light of the provisions of Art. 3 of the Labour Code, the status of an employer is also granted to natural persons who employ employees. However, this provision does not specify the factors that define employer's capacity. Thus, a question arises, whether the provisions of Art. $22 \$ 2$ and 3 of the Labour Code are applicable in this situation. Personally, I support the opinion that the application of the directive a simili is acceptable only in the event of a generic or functional resemblance between the entities. These mechanisms do not occur for employee and employer. In this situation, to define the 
status of a natural person being an employer more precisely, one should apply the general provisions of the Civil Code through Art. 300 of the Labour Code.

The starting point for the analysis of the status of an employer being a natural person will be the statement that, pursuant to Art. 8 of the Civil Code taken together with art. 300 of the Labour Code, all human beings have a legal capacity from the moment they are born. Moreover, another provision that is applicable to the employment relationship is Art. $927 \$ 2$ of the Civil Code concerning the nasciturus, as it has a conditional ability to inherit, lege not distinguente, also in employment relationships, as it may become an heir if it is born alive.

From the perspective of Art. 3 of the Labour Code, it is irrelevant for the status of an employer whether the natural person conducts business or professional activity (cf. judgment of the Voivodeship Administrative Court in Warsaw of 22 November 2016, III SA/Wa 2694/15, LEX 2260907), or whether he or she employs employees on its own behalf, in order to satisfy his or her own demands. This view is justified by the lege non distinguente argument. Here, it is worth quoting the relevant judgment of the Supreme Court of 14 March 2001, II UKN 274/00 (OSNP 2002, No. 21, item 533), which stated that a natural person may be an employer also if the work performed for him or her is not connected to their business activity.

When analysing the status of an employer being a natural person, the status of private partnerships raises certain doubts. In particular, it is doubtful, whether it is the private partnership ${ }^{3}$ or its partners who have the status of an employer. A private partnership cannot be treated as an employer, because it is a type of civil law agreement. ${ }^{4}$ This mechanism correlates with the provisions of Art. 864 of the Civil Code that stipulate that bear joint and several liability for the partnership's obligations. This enables us to draw the conclusion that the enterprise (Art. $55^{1}$ of the Civil Code), created under such partnership cannot employ employees in its own name and that it acts on the account of the partners (Mieroszewski 2000, pp. $33 \mathrm{ff}$; cf. also judgment of the Supreme Court of 17 June 2014, II UZ 34/14, LEX 147088, thesis 1; judgment of the Administrative Court in Katowice of 21 February 2018, III AUa 422/17, Biul. SAKa 2018, No. 2, item 47). Thus, an employee who pursues his or her claims under the employment relationship should sue all partners. Enforcement from the joint property also requires an enforcement title against the partners together (Art. 778 of the Civil Procedure Code).

In collective labour law, pursuant to the provisions of Art. $1^{1}$ item 2 of the Act on Trade Unions, the status of an employer is granted to an entity that employs at least

3 The jurisprudence of the Supreme Court on that matter was highly varied, adequately to legislation changes. Cf. e.g., resolution of the Supreme Court of 14 January 1993, II UZP 21/92, OSNCP 1993, No. 5, item 69; decision of the Supreme Court of 18 February 1998, II UKN 525/97, OSP 1999, No. 7-8, item 130.

4 In the judgment of 13 March 2012, II PK 170/11 (LEX 1211150), the Supreme Court rightly assumed hat partners-entreprenurs who form a private partnership are not individual employers of the employee, but that each of them acts as an employer only because they are in the private partnership agreement and that the articles of association of the partnership and the provisions of art. $865 \$ 1$ of the Civil Code allow it. 
one person who performs work in return for remuneration. This refers not only to employees as defined in Art. 2 of the Labour Code, but also to persons who perform work in return for remuneration on a basis other than an employment relationship (Baran 2019, p. 34). As a result, under collective labour law, entities that employ persons who perform work based on civil law contracts, self-employed persons, and even officers of public services (e.g. police officers or border guards), have the status of an employer. In Polish legal system, the application of this interpretation of the notion of employer is limited to the Act on Trade Unions, the Act on Employers' Associations and the Act on Resolving Collective Disputes.

The analysis of the definition of an employer provided in Art. $1^{1}$ item 2 of the Act on Trade Unions leads to the conclusion that its scope covers not only employees defined in Art. 3 of the Labour Code, but also other categories of employers. In logical terms, the relationship between these categories is an inclusion, which may be presented in form of the following diagram:

Graphics:

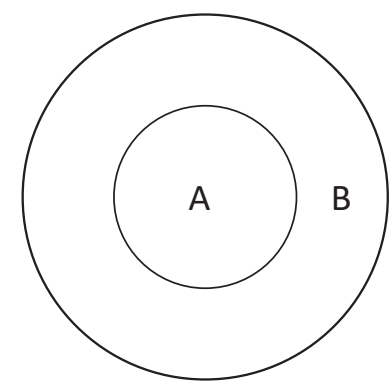

A-employers as defined in Art. 3 of the Labour Code.

B-employers as defined in Art. $1^{1}$ item 2 of the Act on Trade Unions.

Considering the above findings, one may distinguish three categories of employers in the practice of Polish industrial relationships:

1) employers who employ only employees as defined in Art. 2 of the Labour Code.

2) non-employee employers who employ only persons performing paid work on a basis other than an employment relationship as defined in Art. $1^{1}$ item 1 in fine of the Act on Trade Unions.

3) hybrid (heterogeneous) employers who employ both:

a. employees as defined in Art. 2 of the Labour Code and persons performing paid work on a basis other than an employment relationship as defined in Art. $1^{1}$ of the Act on Trade Unions;

b. employees as defined in Art. 2 of the Labour Code and other persons (e.g. voluntaries or persons performing substitute military service;

c. persons performing paid work on a basis other than an employment relationship as defined in Art. $1^{1}$ of the Labour Code and other persons (e.g. voluntaries or persons performing substitute military service. 
In the light of collective labour law, all these employers have the same obligations towards the employed. The regulations do not differentiate their legal status depending on whom they employ in any way.

To conclude the discussion on the notion of the employer in the Polish employment law, one should state that the terminological dualism in this matter generates a series of problems and doubts in practice. However, on the other hand, it allows persons who perform paid work on a basis other than employment relationship and persons who perform unpaid work to defend their rights and interests in the collective sphere. As a result, this mechanism correlates in the action-normative sphere, with the universal notion of trade union freedom.

\section{References}

Baran K.W. (2019) [in:] K.W. Baran (red.), Zbiorowe prawo zatrudnienia. Komentarz, Warszawa. Ćwiertniak B.M. (2010) [in:] K.W. Baran (red.), Prawo pracy, Warszawa.

Hajn Z. (1997) Pojęcie pracodawcy po nowelizacji kodeksu pracy, "Praca i Zabezpieczenie Społeczne," nr 5.

Hajn Z. (2017) [in:] K.W. Baran (red.), System prawa pracy, t. 2: Indywidualne prawo pracy. Część ogólna, Warszawa.

Kaczyński L. (1998) W sprawie jednostki organizacyjnej jako pracodawcy, "Praca i Zabezpieczenie Społeczne," nr 5.

Korus P. (2017) [in:] A. Sobczyk (ed.), Kodeks pracy. Komentarz, Warszawa.

Mieroszewski L. (2000) Czy spółka cywilna jest pracodawca, "Praca i Zabezpieczenie Społeczne," nr 9.

Piwowarczyk K. (2005) Wewnętrzna jednostka organizacyjna spółki jako pracodawca, "Studia z Zakresu Prawa Pracy i Polityki Społecznej."

Tomanek A. (2004) Ogłoszenie upadłości of the możliwościa zawarcia układu a stosunki pracy, "Praca i Zabezpieczenie Społeczne," nr 11.

Wąż P. (2007) Koncepcja pracodawcy rzeczywistego w świetle art. 3 k.p., "Monitor Prawa Pracy," nr 3.

Zając M. (2010) Spółka partnerska jako pracodawca, “Praca i Zabezpieczenie Społeczne," nr 3.

\section{Court sentences}

Judgment of the Voivodeship Administrative Court in Warsaw of 12 December 2006, III SA/Wa 1681/06, LEX 328557.

Judgment of the Voivodeship Administrative Court in Warsaw of 26 June 2008, III SA/Wa 266/08, LEX 402907.

Judgment of the Voivodeship Administrative Court in Warsaw of 22 November 2016, III SA/Wa 2694/15, LEX 2260907. 
Judgment of the Administrative Court in Katowice of 21 February 2018, III AUa 422/17, Biul. SAKa 2018, No. 2, item 47.

Judgment of the Administrative Court in Katowice of 25 October 2018, III APa 82/17, LEX 2612144.

Judgment of the Administrative Court in Katowice of 14 December 2012, III APa 25/12, LEX 1259682.

Resolution of the Supreme Court of 16 November 1977, I PZP 47/77, OSP 1979, No. 7, item 125. Judgment of the Supreme Court of 19 April 1979, IPR 16/79, OSNC 1979, No. 10, item 205. Resolution of the Supreme Court of 24 November 1992, I PZP 59/92, OSNCP 1993, No. 4, item 49. Resolution of the Supreme Court of 14 January 1993, II UZP 21/92, OSNCP 1993, No. 5, item 69. Resolution of the Supreme Court of 23 July 1993, I PZP 30/93, OSNCP 1994, No. 6, item 123. Judgment of the Supreme Court of 19 December 1997, IPKN 448/97, OSNP 1998, No. 22, item 649.

Decision of the Supreme Court of 18 February 1998, II UKN 525/97, OSP 1999, No. 7-8, item 130. Judgment of the Supreme Court of 11 September 1998, II UKN 196/98, OSNP 1999, No. 18, item 589.

Judgment of the Supreme Court of 20 October 1998, I PKN 390/98, OSNP 1999, No. 3, item 744. Judgment of the Supreme Court of 23 February 1999, IPKN 594/98, OSNP 2000, No. 8, item 299. Judgment of the Supreme Court of 1 February 2000, I PKN 494/99, OSNP 2001, No. 12, item 409. Judgment of the Supreme Court of 14 March 2001, II UKN 274/00, OSNP 2002, No. 21, item 533. Resolution of the Supreme Court of the 29 July 2003, III PZP 8/03, OSNP 2004, No. 5, item 75. Judgment of the Supreme Court of 4 November 2004, I PK 25/04, OSNP 2005, No. 14, item 206. Judgment of the Supreme Court of 14 December 2004, I PK 135/04, OSNP 2005, No. 15, item 224. Judgment of the Supreme Court of 20 September 2005, II PK 413/04, OSNP 2006, No. 12-14, item 211.

Judgment of the Supreme Court of 14 June 2006, I PK 231/05, OSNP 2007, No. 13-14, item 183. Judgment of the Supreme Court of 4 January 2008, I PK 187/07, LEX 375669.

Judgment of the Supreme Court of 25 September 2008, II PK 36/08, MPP 2009, No. 10.

Decision of the Supreme Court of 15 December 2009, II PZ 23/09, LEX 577835.

Judgment of the Supreme Court of 4 March 2010, I PK 177/09, LEX 585690.

Judgment of the Supreme Court of 19 April 2010, II PK 298/09, LEX 602256.

Judgment of the Supreme Court of 2 December 2010, I CSK 1ll/10, LEX 1001270.

Judgment of the Supreme Court of 13 March 2012, II PK 170/11, LEX 1211150.

Judgment of the Supreme Court of 18 September 2013, II PK 4/13, LEX 1375183.

Judgment of the Supreme Court of 10 April 2014, I PK 243/13, LEX 1486963.

Judgment of the Supreme Court of 3 June 2014, III PK 128/13, LEX 1486980.

Judgment of the Supreme Court of 4 June 2014, IIUK 565/13, LEX 1475235.

Judgment of the Supreme Court of 17 June 2014, II UZ 34/14, LEX 147088.

Judgment of the Supreme Court of 29 October 2014, I PK 64/14, MPP 2015, No. 4.

Decision of the Supreme Court of 22 June 2015, I PZ 8/15, OSNP 2017, No. 3, item 31.

Judgment of the Supreme Court of 5 September 2017, II UK 365/16, LEX 2401069.

Judgment of the Supreme Court of 14 February 2018, I PK 351/16, LEX 2486199.

Judgment of the Supreme Court of 15 March 2018, I PK 369/16, LEX 2508615. 


\section{Legal acts}

The Civil Code Act of 23 April 1964, Dz.U. 2020, item 1740 consolidated text, as amended. The Civil Procedure Code of 17 November 1964, Dz.U. 2020, item 1575 consolidated text, as amended.

The Labour Code Act of 26 June 1974, Dz.U. 2020, item 1320 consolidated text.

The Act of 23 May 1991 on Trade Unions, Dz.U. 2019, item 263 consolidated text. 